them is likely to be unacceptable. Some institutions have already started to think about the implications for their own students, but widespread consultation does not seem to have taken place. Future practice should be based on a policy decided nationally.

We thank the staff of the medical schools who took the time to complete our questionnaire, and our colleagues Charles Gilks, Fred Nye, Bertie Squire, and Sharon Welby for helpful discussion and comments on the article.

Contributors: Both authors conceived and designed the study and wrote the paper. PJM conducted the telephone enquiries and postal survey.
Funding: None.

Competing interests: None declared.

1 Gilks CF, Wilkinson D. Reducing the risk of nosocomial HIV infection in British health workers working overseas: the role of post-exposure prophylaxis. BMJ 1998;316:1158-60.

2 Expert Advisory Group on AIDS. Guidelines on post-exposure prophylaxis for health care workers occupationally exposed to HIV.London: Department of Health, 1997.

3 Ellis C. Post-tropical screening [letter]. BMJ 1993;307:1008

4 UNAIDS. Report on the global HIV/AIDS epidemic. Geneva: UNAIDS, World Health Organisation, 1998:63-4.

(Accepted 23 October 1998)
AIDS Prevention

Division, Child

Foundation of

India,

Visakhapatnam

530 008, Andhra

Pradesh, India

Kootikuppala Surya

Rao,

director

R D Pilli,

senior associate

A S Rao,

research associate

P S Chalam,

research associa

Correspondence to:

Dr K S Rao, Sri

Surya Clinic

Buildings,

Kancharapalem

Main Road,

Visakhapatnam

530 008, Andhr

Pradesh, India

BMJ 1999;318:162-3

\section{Sexual lifestyle of long distance lorry drivers in India: questionnaire survey}

\author{
Kootikuppala Surya Rao, R D Pilli, A S Rao, P S Chalam
}

India has one of the largest road networks in the world and an estimated 5 million long distance lorry drivers. These men are away from their families for long durations, and in the unhealthy environment along the highways they become easy prey for commercial sex workers. This environment has brought new dimensions to their lifestyle. A recent study of Thai long haul truck drivers found that $86 \%$ of the single men and $63 \%$ of the married men had had commercial sex. ${ }^{1}$ We studied the sexual lifestyle of long distance lorry drivers in India.

\section{Subjects, methods, and results}

A total of 5709 consecutive long distance lorry drivers who consented to take part in the questionnaire survey while passing through a check post on National High- way 5 at the Andhra-Orissa border were interviewed by three trained investigators over 105 days between March 1994 and August 1994. Interviews took 15-20 minutes.

The table shows that $87 \%$ of subjects (4949 men) were sexually promiscuous, of whom only $11 \%$ (563) used condoms during commercial sex. The percentage using condoms decreased with increasing age. In the $21-30$ age group $(n=1766), 78 \%$ of unmarried sexually promiscuous men $(331 / 425)$ reported having 31-60 sexual partners during the past 12 months.

Only 29 of the 40 married men aged under 21 reported having sex daily. Almost half of subjects (2714; 47\%) drank alcohol daily early in the morning and got tremors if they didn't drink; the proportion increased with age, from $34 \%$ in men under 21 to $59 \%$

Sexual behaviour of 5709 long distance lorry drivers in India. Values in body of table are numbers (percentages); values in headings are numbers of respondents to question

\begin{tabular}{|c|c|c|c|c|c|c|c|c|c|c|c|c|}
\hline \multirow[b]{3}{*}{ Age group } & \multirow{3}{*}{$\begin{array}{c}\text { Sexually } \\
\text { promiscuous } \\
(\mathrm{n}=4949)\end{array}$} & \multicolumn{4}{|c|}{$\begin{array}{l}\text { No of sexual partners during past } \\
12 \text { months }\end{array}$} & \multirow{3}{*}{$\begin{array}{c}\text { Regular } \\
\text { condom use in } \\
\text { past } 12 \text { months } \\
\text { during } \\
\text { commercial sex } \\
(n=563)\end{array}$} & \multirow{3}{*}{$\begin{array}{c}\text { AIDS } \\
\text { knowledge† } \\
(\mathrm{n}=3997)\end{array}$} & \multicolumn{3}{|c|}{ Sexual practice‡ } & \multirow{3}{*}{$\begin{array}{l}\text { Alcohol } \\
\text { misuse§ } \\
(\mathrm{n}=2714)\end{array}$} & \multirow{3}{*}{$\begin{array}{c}\text { Sexually } \\
\text { transmitted } \\
\text { diseaseף } \\
(\mathrm{n}=1748)\end{array}$} \\
\hline & & \multirow[b]{2}{*}{$\leqslant 30$} & \multirow[b]{2}{*}{$31-40$} & \multirow[b]{2}{*}{$41-50$} & \multirow[b]{2}{*}{$51-60$} & & & \multirow{2}{*}{$\begin{array}{c}\text { Vaginal sex } \\
\text { only } \\
(\mathrm{n}=4572)\end{array}$} & \multicolumn{2}{|c|}{ Vaginal sex plus: } & & \\
\hline & & & & & & & & & $\begin{array}{c}\text { Anal sex } \\
(n=162)\end{array}$ & $\begin{array}{l}\text { Oral sex } \\
(n=215)\end{array}$ & & \\
\hline \multicolumn{13}{|l|}{ <21 years: } \\
\hline Married $(n=61)$ & $40(66)$ & 19 & 10 & 5 & 6 & $31(78)$ & $39(64)$ & $36(90)$ & $2(5)$ & $2(5)$ & & $28(70)$ \\
\hline Unmarried $(n=166)$ & $111(67)$ & 54 & 15 & 22 & 20 & $4(4)$ & $124(75)$ & $107(96)$ & $2(2)$ & $2(2)$ & & $60(54)$ \\
\hline Total $(n=227)$ & $151(66)$ & 73 & 25 & 27 & 26 & $35(23)$ & $163(72)$ & & & & $76(34)$ & $88(58)$ \\
\hline \multicolumn{13}{|l|}{ 21-30 years: } \\
\hline Married $(n=1087)$ & $978(90)$ & 614 & 163 & 93 & 81 & $102(10)$ & 701 (64) & 967 (98) & $5(1)$ & $6(1)$ & & $360(37)$ \\
\hline Unmarried $(n=679)$ & $425(63)$ & 94 & 66 & 143 & 122 & $16(4)$ & $581(86)$ & $413(97)$ & $7(2)$ & $5(1)$ & & $260(61)$ \\
\hline Total $(n=1766)$ & $1403(79)$ & 735 & 229 & 236 & 203 & $118(8)$ & $1282(73)$ & & & & $656(37)$ & $620(44)$ \\
\hline \multicolumn{13}{|l|}{ 31-40 years: } \\
\hline Married $(\mathrm{n}=2408)$ & 2207 (92) & 1417 & 590 & 189 & 11 & $216(10)$ & $1803(75)$ & 2060 (94) & $61(3)$ & $86(4)$ & & $704(32)$ \\
\hline Unmarried $(n=190)$ & $134(71)$ & 59 & 23 & 35 & 17 & $71(53)$ & $81(43)$ & $104(78)$ & $12(9)$ & $18(13)$ & & $52(39)$ \\
\hline Total $(n=2598)$ & $2341(90)$ & 1476 & 613 & 224 & 28 & $287(12)$ & $1884(72)$ & & & & $1320(51)$ & $756(32)$ \\
\hline Married $(n=1060)$ & $1012(95)^{\star *}$ & 528 & 284 & 140 & 60 & $101(10)$ & $641(60)^{* *}$ & $866(86)$ & $69(7)$ & 77 (8) & & $280(28)^{* \star}$ \\
\hline Unmarried $(n=58)$ & $42(72)^{\star *}$ & 18 & 9 & 15 & 0 & $22(52)$ & $27(47)^{\star *}$ & $19(45)$ & $4(10)$ & $19(45)$ & & $4(10)^{* \star}$ \\
\hline Total $(n=1118)$ & $1054(94)^{* *}$ & 546 & 293 & 155 & 60 & $123(11)$ & $668(60)^{* *}$ & & & & $662(59)^{\star}$ & $284(27)^{\star * *}$ \\
\hline
\end{tabular}

${ }^{*}$ Frequent and indiscriminate change of sexual partners, irrespective of marital status. †Correct answers to questions about the transmission and severity of AIDS.

fUsual practices during previous 12 months by men who had extramarital sex. §Drink daily early in the morning and get tremors if they don't drink.

१Genital ulcer, genital discharge, or both, during last 12 months, in men who had extramarital sex. ${ }^{*}{ }^{*} P<0.001, \chi^{2}$ test, compared with men aged $<21$ years. 
in men over 40. Of the men interviewed, $69 \%$ (3938) were educated-that is, they could read and write fluently in their mother tongue or had a higher qualification. A significantly higher proportion of men over 40 , compared with men under 21, were sexually promiscuous and misused alcohol and a lower proportion had AIDS knowledge $\left(\mathrm{P}<0.001, \chi^{2}\right.$ test; table).

\section{Comment}

During their journeys, long distance lorry drivers stop at "dhabas," roadside hotels that usually provide food, rest, sex workers, alcohol, and drugs. They pick up the women, use them, and leave them at some other dhaba, where they are used by other drivers and local youths. Thus long distance lorry drivers are crucial in spreading sexually transmitted diseases and HIV infection throughout the country in a short time. They have an HIV infection rate of $10 / 1000$, far higher than the Indian national average of about $0.5 / 1000 .^{3}$

We found that drivers aged over 40 were highly vulnerable, and the potential for transmission of sexual diseases by this group is the most threatening. Though their AIDS knowledge is fairly good, their use of condoms is poor. As in Tanzania, ${ }^{4}$ condom use should be promoted along truck routes by distributing condoms freely along national highways through condom outlets. Research is urgently needed to find effective strategies to persuade lorry drivers to change their hazardous sexual behaviour.

We thank the authorities of Srikakulam District, Department of Commercial Taxes, Government of Andhra Pradesh, for permitting us to work at the check post. We also thank the long distance lorry drivers for their full cooperation.

Contributors: RDP coordinated the study; PSR participated in the protocol design and analysis and interpretation of data; ASC participated in data collection and analysis; KSR wrote the paper and is guarantor.

Funding: AIDS Prevention Division of the Child Foundation of India, Visakhapatnam.

Conflict of interest: None.

1 Institute for Population and Social Research, Mahidol University, Bangkok. Behaviour pattern of Thai long haul truck drivers. In: Bloom DE, Lyons JV. Economic implications of AIDS in Asia. New Delhi: UNDP Regional Bureau for Asia and the Pacific, 1993:80-1.

2 Joseph L Fleiss JL. Statistical methods for rates and proportions. 2nd ed. New York: Wiley, 1981:138-43.

3 Singh YN, Singh K, Joshi R, Rustagi GK, Malaviva AN. HIV infection among long distance truck drivers in Delhi India; AIDS and Asia: development crisis. New Delhi: Department of Medicine, All India Institute of Medical Science, 1992. (UNDP Regional Project on HIV/AIDS.)

4 Huddart J. HIV in the work place: Dealing with issues-role plays. Boston: United Nations Development Programme, 1993.

(Accepted 5 May 1998)

\section{Tales of crack Some quotes from patients and their doctors}

Crack cocaine, also known as freebase or Charlie, is a compound of cocaine which is smoked, giving rapid absorption via the lungs and a brief "rush" of euphoria, with feelings of invincibility. It inhibits monoamine reuptake by binding to dopamine, noradrenaline, and serotonin system membrane transporters. Its half life is 50 minutes, and dysphoria-possibly caused by dopamine depletion-may rapidly follow. Twenty per cent of experimenters are said to become regular users. A small "rock" of crack can cost a few pounds. Crack has become widely available on the drug scene in the past 10 years. Its use is said to be linked with violent crime and prostitution. Some users start on opiates to deal with dysphoria related to crack.

No substitution treatment is available, but dopamine reuptake blockers such as desipramine are being investigated.

"I used to take up to $£ 4500$ worth in one week. I got the money by going up to London on the train and working the big hotels. As well as that I'd steal credit cards from the hotel rooms. I was such a good earner that one gang sold me to another. Now I've got nowhere to live and my kids are in care. I'm afraid somebody is going to kill me." [Prostitute, aged 28]

"If you've taken $£ 300$ worth of crack in one day you are just a person of no account, worth no respect. A decent person, someone worthy of 'respect,' will take $£ 600$ or $£ 1000$ worth. When you've taken that much there's only one thing you want to do, do it again. The first time you take it is really good. Every time you take it after that it's never as good. You're forever trying to recapture that first time experience. There's no harm reduction programme for crack." [Civil servant, ex-user, aged 40]

"I'd been to night school, worked really hard to get qualifications, got my own flat together, and a new car. Everything was going really well, then one weekend I got really down; I sold my car in the club for $£ 1800$ and spent it all on crack. [Clerk, aged 26]

"He was bailed back home to us; I kept him in all week, and he seemed okay, then he climbed out of the bathroom window and didn't come home for three days; he went straight back on the crack again." [Mother of 18 year old] "When I took crack I felt that I was king for a minute, but the whole effect would be over in 10 minutes. The easiest way to stop coming down was to take more. I took as much as $£ 750$ worth in a day. You can get that kind of money by stealing new cars; they give you $£ 1000$ for one and clone it." [Her son]

"I was spending $£ 200$ a day on it, working as an escort; then this man pulled a gun on me and attacked me when I got in his truck. He might have killed me; lots of people change just like that on it. I know people with money who take it, solicitors, businessmen. Now I'm scared to work, I've got no money, so I've had to stop taking it. I just get depressed all the time now." [Prostitute, aged 26]

"He hid in the health centre lavatory until the staff had left, then came into my room in a really agitated and angry state, told me he'd taken $£ 350$ worth of crack in there, that he had a weapon and was going to kill me; then he went through my desk." [Local GP]

"If he takes crack his lithium won't work." [Forensic psychiatrist] "We haven't got a great deal to offer in the way of managing crack cocaine addiction; our resources are already overwhelmed by our existing opiate users." [Consultant at local drug problem team]

Stefan Cembrowicz, general practitioner, Bristol

We welcome articles of up to 600 words on topics such as $A$ memorable patient, A paper that changed my practice, My most unfortunate mistake, or any other piece conveying instruction, pathos, or humour. If possible the article should be supplied on a disk. Permission is needed from the patient or a relative if an identifiable patient is referred to. We also welcome contributions for "Endpieces," consisting of quotations of up to 80 words (but most are considerably shorter) from any source, ancient or modern, which have appealed to the reader. 